\title{
Chapter 1 \\ Introduction: Parental Life Courses After Separation and Divorce in Europe
}

\author{
Michaela Kreyenfeld and Heike Trappe
}

\section{Introduction}

Divorce rates are stagnating at high levels in most European countries. We lack finegrained data from official sources that map divorce and, in particular, the separation rates of couples with children over time. Nevertheless, the survey data tell us that a large fraction of children experience the divorce or separation of their parents before they reach adulthood (Andersson et al. 2017). Union disruption is always a distressing event, and it is most consequential for couples with minor children. Even after their union ends, the ex-partners have to stay in contact to coordinate and negotiate their parental responsibilities. In most cases, separation and divorce mean that the family splits into separate households. While women usually continue to reside with their children, men may find it increasingly difficult to maintain close contact with their children. Little is known about how parents organise childcare responsibilities after separation and divorce, or about the conditions under which fathers remain involved in the lives of their children (Albertini and Garriga 2011; Kalmijn 2015). In addition, divorce and separation often lead to economic hardship and distress. Parents may adopt different strategies to overcome the adverse consequences of divorce and separation. "Re-partnering" and "re-employment" can be viewed as competing strategies that women may use to ameliorate the economic consequences of divorce and separation (see also Mortelmans in this volume). While this framework can be criticised for providing a simplistic view of mothers' partnership and employment choices, it nevertheless highlights the importance of employment and

\author{
M. Kreyenfeld $(\bowtie)$ \\ Hertie School, Berlin, Germany \\ e-mail: kreyenfeld@hertie-school.org \\ H. Trappe \\ Institut für Soziologie und Demographie, Universität Rostock, \\ Rostock, Mecklenburg-Vorpommern, Germany
}


partnership transitions for parental well-being after the breakdown of a union (Jansen et al. 2009). Prior research has shown that there are gender differences in re-partnering patterns after separation and divorce (Gałęzewska et al. 2017; Ivanova et al. 2013). In addition, gender differences in the economic consequences of divorce have been examined for several countries and compared across time (Andreß et al. 2006; Popova and Navicke 2019; Raeymaeckers et al. 2008). However, most of these prior studies did not focus on parents, but instead examined all couples, regardless of whether they had minor children at the time of divorce or separation. As a consequence, we still know relatively little about the life courses of divorced and separated couples with children, at least for European countries (for the US, see, however, Cancian et al. 2014; Meyer and Carlson 2014; Musick and Michelmore 2018). The question of how the life course and gender role behaviour prior to divorce and separation affect the behaviour and well-being of mothers and fathers after the breakdown of a union also merits further investigation. Moreover, how the economic situation of parents is affected by child and spousal support payments, and whether social policies can effectively alleviate some of the economic consequences of divorce and separation, are issues that have yet to be fully addressed.

This volume seeks to close part of this research gap. The European context is an ideal laboratory for studying how political and cultural factors influence postseparation behaviour. The widely varying social policies and legal regulations that exist across European countries enable researchers to contextualise and gain a better understanding of how social policy regulations affect behaviour and parental and child well-being after divorce and separation. In this monograph, we assemble studies from a range of European countries that explore four major and interconnected themes of family life after divorce and separation. We address (a) economic conditions, (b) parent-child relationships, (c) parent and child well-being, and (d) the health-related consequences of divorce and separation. All of the studies included in this volume take a longitudinal perspective and situate post-separation behaviour and well-being in the life course. The longitudinal perspective opens up new avenues for research that seeks to understand how individuals' behaviour and conditions prior to or at the time of a divorce or separation affect their later behaviour and well-being. Before we provide an overview of the contributions of this volume, we summarise the broad trends in divorce and separation, as well as in attitudes towards divorce, in Europe. This overview must remain very general. Due to the lack of comparable data, we do not address the specific situations of unmarried couples and couples with children. Instead, we provide a broad picture of overall divorce trends. 


\section{Divorce and Separation in Europe}

\section{Divorce in Europe: A Trend Reversal or an Artefact of a Demographic Measure?}

Apart from Vatican City, married couples are now legally allowed to divorce in all European countries (for an overview, see Spijker and Solsona 2012). The first European country to liberalise its divorce laws was Iceland, where divorce has been permitted since the sixteenth century. Divorce was legalised in 1791 in France and in 1794 in Luxembourg. Other European countries followed suit in the nineteenth century. Among the laggards in this trend were the southern European countries and Ireland. Divorce was not legally permitted until 1970 in Italy, until 1975 in Portugal, and until 1981 in Spain (although divorce was briefly permitted in 1934-1936 during the Second Spanish Republic). Ireland did not liberalise its divorce laws until 1995 (see chapter by Moore in this volume). ${ }^{1}$ Although divorce is now legally permitted, the social policy context in which divorce and separation occur continues to differ strongly across European countries. A few countries still allow fault divorce, such as France and Poland. Others, such as Italy and Germany, used to mandate long separation periods before a divorce was granted. Overall, the trend towards reduced state control over marriage and divorce has changed the divorce process and the dynamics of marriages. Unilateral divorce laws shifted the balance of power towards the spouse who is more willing to exit the union. Furthermore, the shortening of the legal process as well as the abolition of fault divorce have helped to make getting divorced a faster and less conflict-ridden process than it was in the past (Härkönen 2014: 4). Changes in gender roles and in the work behaviour of women have resulted in separated parents sharing childcare duties more equally after divorce and separation. Shared physical custody is increasingly being implemented into the legal framework of some countries, while in other countries it is still the norm for one parent to be granted sole physical custody (Claessens and Mortelmans 2018).

How do divorce law and divorce behaviour relate to each other? Has the liberalisation of divorce laws resulted in higher divorce rates? Or are "high divorce countries" simply more open to enacting liberal divorce laws and gender-equal custody regulations? Efforts to compare divorce and separation behaviour across countries have, unfortunately, been greatly limited by a lack of comparable and suitable data. The only indicator that is available for (almost) all European countries for a longer time period is the crude divorce rate (CDR). The CDR divides the number of divorces in a country by its population size (multiplied by 1000). Figure 1.1 maps this measure for the years 1990, 2000, 2010, and 2017. Looking at the figure, we

\footnotetext{
${ }^{1}$ Most western European countries, such as Austria, Germany, Belgium, Denmark, Sweden, the Netherlands, and England and Wales, liberalised their divorce laws in the course of the nineteenth century. An exception is Scotland, which did not liberalise its divorce laws until 1976. Malta is another outlier that did not allow divorce until 2011.
} 


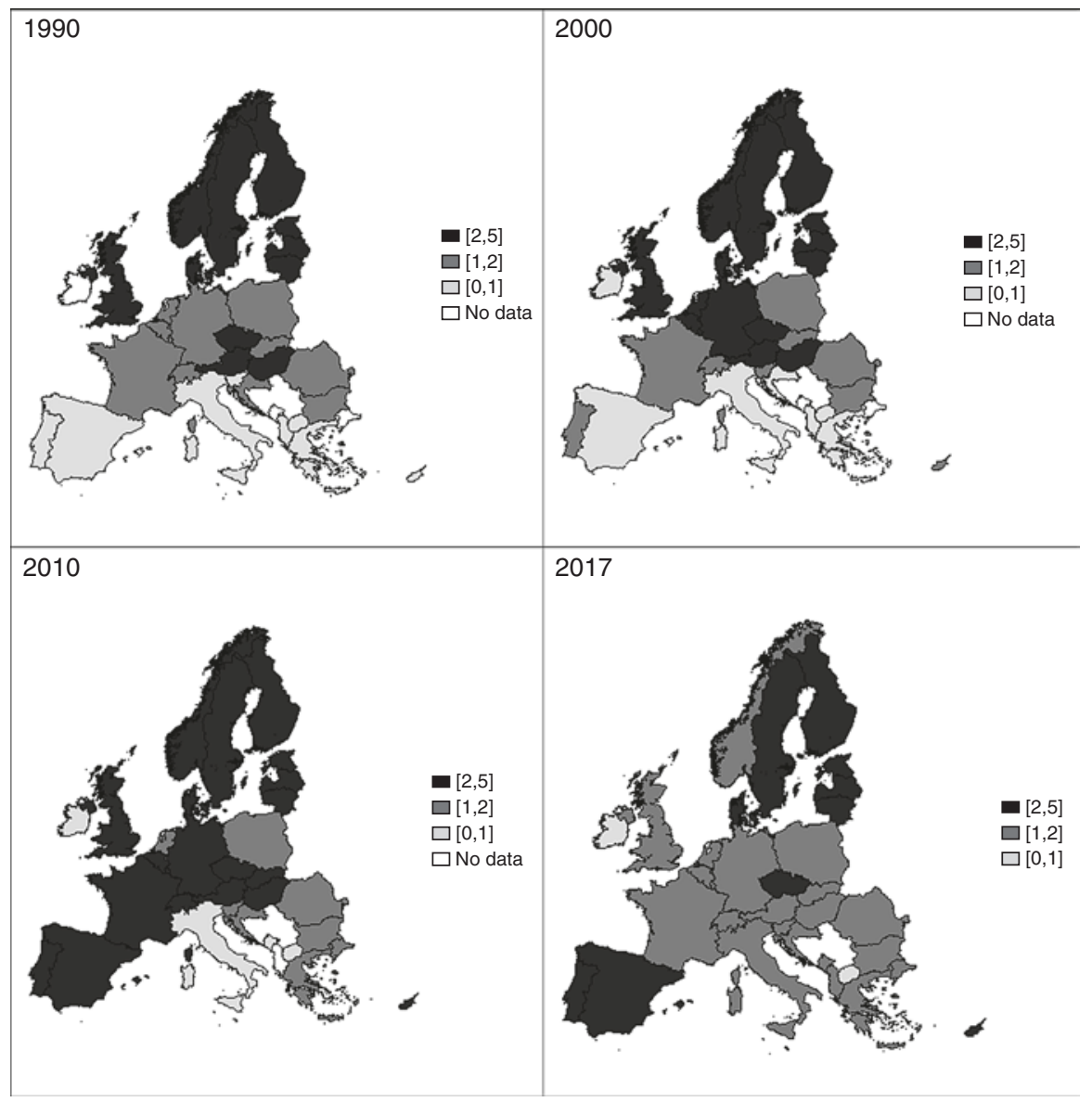

Fig. 1.1 Crude divorce rate in Europe 1990, 2000, 2010, 2017

Source: Eurostat (2019), own representation (based on the "spmap-ado" of STATA)

Notes: Only countries with valid information for 2017 are displayed. For Italy and Latvia, data for 2017 were imputed based on data from 2016. Data for Ireland for 2017 were imputed based on data from 2015

can see that in 1990, there was a regional divide characterised by high divorce rates in the Nordic countries and much lower divorce rates in southern Europe. Divorce rates were at intermediate levels in western and central and eastern European countries, except in Austria, the Czech Republic, and Hungary which had elevated CDRs. The figure also shows that by 2010 , these patterns had changed, as higher divorce rates seem to have spread from northern to western Europe. This shift has been described in detail by proponents of the Second Demographic Transition Theory (SDT) who cited an increase in divorce as an "early sign" of a shift towards a more secularised society with more liberal family attitudes and family behaviour (Lesthaeghe 1983, 2010). The most recent data available from Eurostat are for 2017. 
The figure indicates that by this year, cross-country differences in divorce rates seem to have narrowed. Most importantly, however, the figure shows that in many former "high divorce countries", the CDR has declined. When more refined measures such as the total divorce rate (TDR) are applied, we still find a decline or a recent levelling off in divorce intensities in certain countries, such as Denmark, Finland, Germany, the Netherlands, Norway, Portugal, Sweden, and the UK. There is considerable debate about how this decline in divorce rates should be interpreted. As fewer people marry or delay marriage until later in life, fewer people are divorcing. In addition, as those individuals who marry appear to be a selective population with more traditional views, their unions are likely to be more stable (Cohen 2019). In order to study the changes in union stability, we would need information on the duration of all unions, regardless of whether the couples are married. Unfortunately, most countries do not collect such information. Furthermore, we lack comparable information on the question of whether unions with children have become more stable over time.

Some information on the stability of unions with children is available from social science surveys. Andersson et al. (2017) used data from the Generations and Gender Survey (and related surveys) to estimate the probability of children under age 15 being affected by the dissolution of their parents' union. They found that in countries such as France, Belgium, Sweden, Austria, Estonia, Lithuania, the Czech Republic, and Hungary, about one-third of children have experienced the break-up of their parents' union. The study also reported very high parental separation probabilities of $40 \%$ for the US and Russia, and relatively low probabilities in southern European countries (such as Spain and Italy) and in Germany, where "only" around $10-20 \%$ of children have been affected by the dissolution of their parents' union. The findings of social science surveys also suggest that the relationship between education and marital stability has reversed its sign in recent years. While divorce had been more prevalent among the highly educated, the differences in divorce rates between educational groups have levelled off in recent years (Härkönen 2014). In many countries, such as Belgium, the UK, the Netherlands, and the Nordic countries, separation is now more common among the less educated than the highly educated (Matysiak et al. 2014; Van Bavel et al. 2018). There is also solid evidence that non-marital unions are less stable than marital unions, and that, in most countries, education is negatively correlated with having children in a non-marital relationship (Bennett 2017; Schnor 2014). The negative correlation between education and non-marital childbearing has sparked a debate about the effects of family change on the well-being of children. In a landmark article entitled "Diverging destinies: How children are faring under the Second Demographic Transition", McLanahan (2004) argued that the Second Demographic Transition theory (see above) had glorified the shift towards liberal attitudes, while disregarding the negative consequences that increasing rates of divorce and separation may have on the social and economic well-being of children and parents. However, comparative research has shown that social, cultural, political, and economic developments moderate the negative effects of union dissolution on parents and children (Perelli-Harris and Lyons-Amos 2016). 


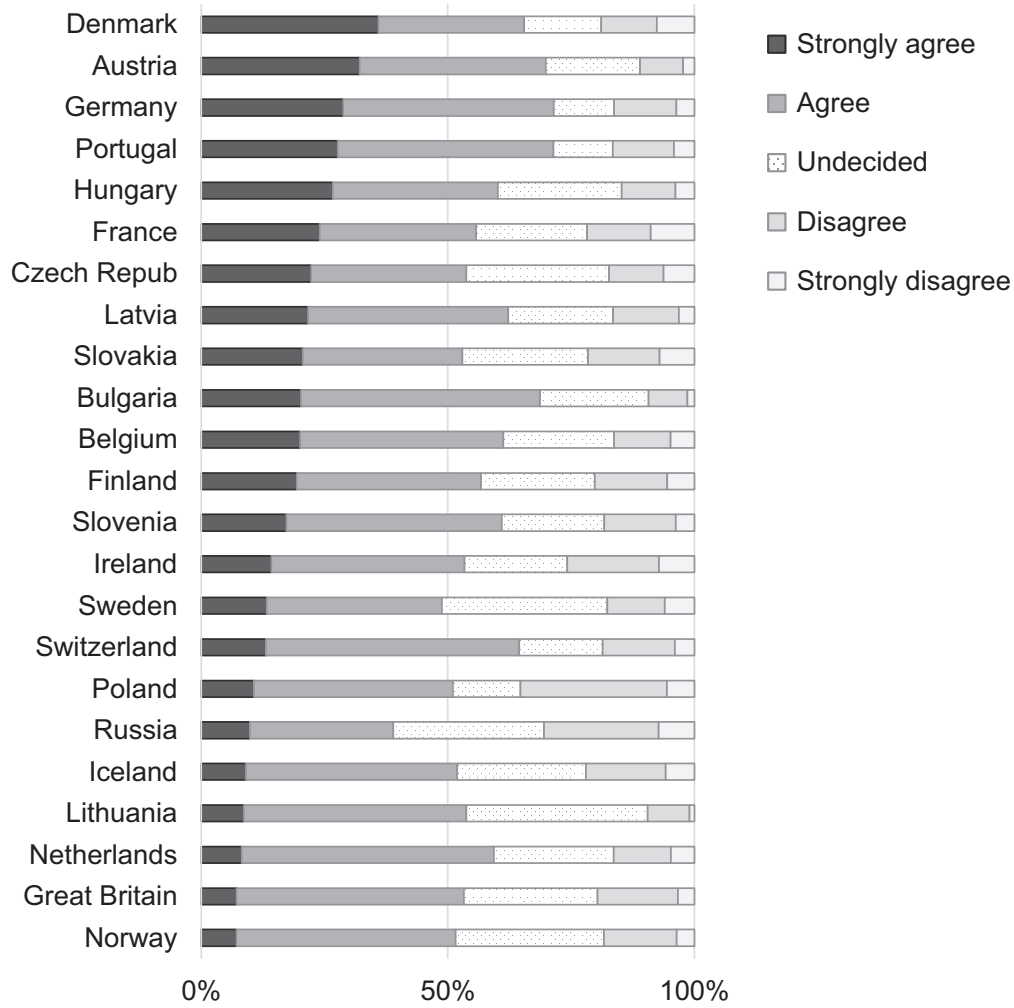

Fig. 1.2 Probability of agreeing with the statement: "Divorce is usually the best solution when a couple can't seem to work out their marriage problems". 2012

Source: Data come from the ISSP 2012 (ISSP Research Group, 2016)

\section{Attitudes Towards Divorce: A Comparison of Data from 1994, 2002, and 2012}

There is no longer a clear regional pattern in divorce rates, as measured by the CDR. This may be because of the many limitations of this indicator. But can we discern a clearer pattern in attitudes towards divorce across Europe? To answer this question, we employed data from the International Social Science Survey (ISSP), which collected information on family-related issues in 1994, 2002, and 2012 (ISSP Research Group 1997, 2013, 2016). ${ }^{2}$ Figure 1.2 displays the results for the year

\footnotetext{
${ }^{2}$ The sample includes respondents aged 20-79 with valid information on the key variable of interest (divorce attitudes): "Divorce is usually the best solution when a couple can't seem to work out their marriage problems". Agreement was measured on a five-point Likert-scale with "strongly agree", "agree", "neither agree nor disagree", and "disagree strongly" as the response options. "Strongly agree" and "agree" were grouped into one category. Undecided and missing values were eliminated (except in Figure 1.2). For Spain in 2012, only a four-point scale was used; i.e., "neither agree nor disagree" was not included.
} 


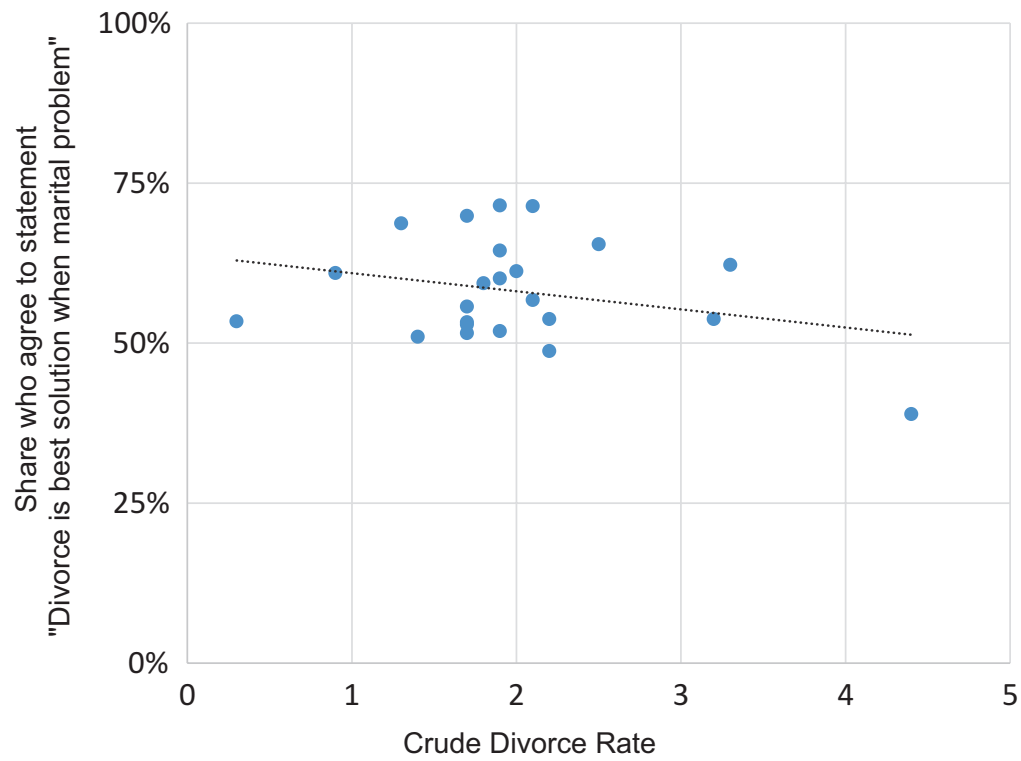

Fig. 1.3 Scatterplot of the crude divorce rate in 2012 and the share of people who agreed with the statement: "Divorce is usually the best solution when a couple can't seem to work out their marriage problems". 2012

Source: ISSP 2012 (weighted estimates) and Eurostat (2019)

Notes: The CDR for Russia for 2012 was imputed based on data from 2011

2012 for the item "Divorce is usually the best solution when a couple can't seem to work out their marriage problems". In most countries, about $50 \%$ of the population agreed or strongly agreed with that statement. However, the figure also shows that there is no clear regional pattern in responses to this question. It appears that countries that are commonly assumed to be rather traditional in their family values, such as Austria and Germany, are very open to divorce. In Sweden, the vanguard of a de-familiarised society, acceptance of divorce seems to be low. It is possible that this pattern can be attributed to differences in how the question is translated into the native language. Moreover, differences in the country-specific response patterns might have affected this comparison (Weziak-Bialowolska 2015). It is also possible that as levels of divorce have increased, public awareness of its adverse consequences is growing as well. However, the findings displayed in Fig. 1.3, in which the crude divorce rate and the attitudes towards divorce in a country are correlated, provide only slight support for this claim. The figure shows that as divorce rates increase, the share of people who agree with the statement that divorce is the best solution for a couple facing marital problems declines. However, this relationship is very much driven by Russia, where both divorce and opposition to divorce are high. Overall, attitudes towards divorce do not seem to be highly correlated with the CDR. This finding is in line with the results of a previous analysis by Rijken and 


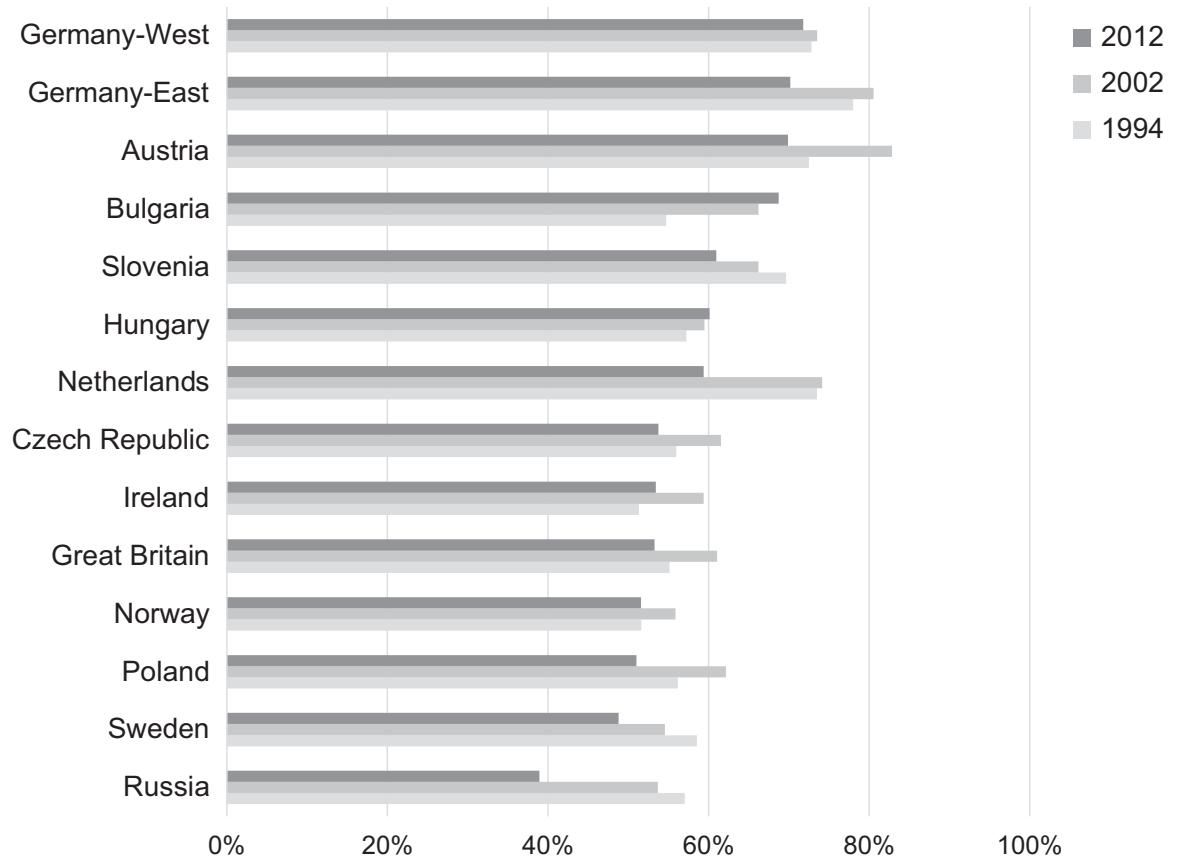

Fig. 1.4 Share of people who agree or strongly agree with the statement: "Divorce is usually the best solution when a couple can't seem to work out their marriage problem". 1994, 2002, 2016 Source: Data come from the ISSP 1994, 2002, 2012 (ISSP Research Group, 1997, 2013, 2016), weighted estimates. Data for Great Britain without Northern Ireland are used for 1994 and 2002

Liefbroer (2012), who correlated the CDR with attitudes towards divorce based on data from the third wave of the European Social Survey conducted in 2006/07.

To gain a better understanding of how attitudes have changed across time, we pooled the data for all available years $(1994,2002,2012)$. The results for the countries that are included in all three survey years are displayed in Fig. 1.4. A comparison of the responses in the years 1994 and 2002 suggests that there was an initial liberalisation of attitudes towards divorce. However, we also see evidence of a strong backlash, with attitudes towards divorce becoming more conservative in almost all countries from 2002 to 2012. This backlash was especially pronounced in the Netherlands and Russia. Of the countries included in this comparison, West Germany, Hungary, and Bulgaria are the only countries where no major decline in acceptance of divorce occurred between 2002 and 2012. These results, which suggest that there has been a "re-traditionalisation" of divorce attitudes across Europe, are partially at odds with the conclusions of prior investigations. Halman and van Ingen (2015), who examined data from the European Value Survey 1981-2008, found that attitudes towards divorce have become more liberal in western Europe, and have not changed over time in eastern Europe. The findings of our investigations do not support the existence of an East-West divide. They neither indicate that 
values have become more liberal in western European countries in recent years. The differences between the outcomes of our analysis and those of the study by Halman and van Ingen (2015) may be attributable to differences in the observation periods used; i.e., our data go up to 2012, while their data only go up to 2008. Furthermore, the investigation by Halman and van Ingen (2015) modelled the linear effects of calendar time in a regression framework. Our investigation is more descriptive, but shows that there has been a non-linear development. It thus appears that although attitudes towards divorce had become more liberal by the turn of the century, there has been a backlash in recent years. These findings stand in stark contrast to widely held predictions, in particular of the Second Demographic Transition, that there would be a steady liberalisation of family values in advanced economies.

\section{Summary of the Contributions in this Volume}

This book is structured to enable us to focus on four main areas: namely, economic conditions, parent-child relationships, parental and child well-being, and health. Dimitri Mortelmans (University of Antwerp, Belgium) introduces the section on the economic consequences of divorce and separation (Part I) with a review of the prior findings. His overview discusses the different "coping strategies" that parents adopt to overcome the adverse economic effects of divorce and separation. It is an established finding that after union dissolution, a woman's equalised household income is likely to decline more sharply than a man's. While many women leave the labour market or reduce their working hours after having a child, undergoing a separation or divorce may prompt them to expand their labour supply. Re-partnering is often seen as an alternative strategy for improving the economic well-being of the household. Mortelmans points out that returning to the parental home is yet another potential reaction to the dissolution of a union, but notes that we currently know little about the "boomeranging" of parents who return to their own parent's household after a union dissolution. Another gap in the literature pertains to the role of social policies in ameliorating the economic consequences of divorce and separation. Mortelmans explains that the gendered consequences of divorce vary radically depending on the welfare state arrangements, particularly with regard to childcare availability and women's options for working. He emphasises, however, that we currently know relatively little about how the different policy instruments (exspousal maintenance, child alimony, social benefits, etc.) affect parents' coping strategies after a union dissolution, or the economic well-being of families.

Anna-Karin Nylin (Stockholm University, Sweden) uses rich Swedish register data to focus on employment as a strategy for coping with the decline in equalised income after divorce and separation. She makes the argument that divorce and separation may be beneficial for the development of earnings. As partnered women frequently reduce their working hours or withdraw from the labour market after having a child, their human capital can decay. Conversely, separated women are often pushed into the labour market. If these women remain attached to the labour market, 
they could have more stable and positive earnings trajectories over the long term. While the argument is compelling, Nylin refutes this hypothesis based on her data. She reports that the earnings developments of separated and partnered women with children are very similar, and that 8 years after a separation, the earnings of separated mothers even lag behind those of partnered women with children. Her findings further indicate that this pattern is particularly pronounced among women in the lowest earning brackets. Nylin concludes her investigation with a discussion of the direction of Swedish family policies. Swedish family policies are often regarded as a template for other countries, as they rigorously adhere to the ideal of gender equality in the labour market. Promoting full-time employment is seen as the most effective policy for shielding families from poverty. Her investigation suggests that this strategy may be successful for the majority of the population, but that there are subgroups in the lower earnings brackets who may have difficulties establishing themselves in the labour market. She warns that separation and divorce may represent an additional risk factor for this particular group.

Anke Radenacker (Hertie School, Germany) also draws on rich administrative data to examine mothers' earnings trajectories after divorce. Her data include divorced women in western Germany. Unlike Sweden, (West) Germany has until very recently been classified as a conservative welfare state. While rates of part-time employment have been rising, women's options for full-time employment have been greatly constrained by the restricted opening hours of day care centres as well as by the traditional view that the mother should be solely responsible for caring for her children in the first years of life. Many married women withdraw completely from the labour market after childbirth or work in marginal or part-time positions. She shows that maternal employment rates have been increasing among recent divorce cohorts, and especially among those cohorts who were affected by the change in the maintenance law in 2008, which scaled back ex-spousal maintenance payments. She also observes that a woman's employment and earnings trajectories during her marriage tend to determine her employment and earnings after her divorce. Radenacker emphasises, however, that these results must be contextualised. Unlike in Sweden, there is considerable potential for women in Germany to increase their working hours after a divorce given their low employment rates during marriage. She also reports that even though divorce pushes women towards economic independence, women's earnings lag far behind those of men: i.e., on average, women in Germany earn only $40 \%$ of men's earnings after a divorce. These findings stand in stark contrast to the Swedish results outlined above.

While Nylin and Radenacker examine how parents use increased employment and earnings to deal with the adverse effects of divorce and separation, the next paper highlights a different coping mode. Dimitri Mortelmans, Layla Van den Berg, and Gert Thielemans (all University of Antwerp, Belgium) focus on the return to the parental home as a strategy parents use to ameliorate the adverse effects of divorce and separation. Like the studies mentioned above, the investigation relies on largescale register data. The main result of this investigation is that these patterns are highly gendered, with fathers being more likely than mothers to return to the parental home after union dissolution. A potential explanation for this finding is that 
women are more likely than men to be living with their children after separation, which makes moving into their parents' home a more complex proposition. They also find that parents on welfare are less likely to use this coping strategy, possibly because they may no longer qualify for means-tested benefits if they move in with their own parents. The authors also look at differences in these patterns by migration background. They find that while there are hardly any differences between individuals with Moroccan and Belgian citizenship, Turkish nationals stand out as having a high probability of returning to the parental home. Overall, the paper demonstrates that in order to understand these patterns, welfare state incentives and cultural factors must be taken into account.

The section on parent-child relationships (Part II) starts with a contribution by Ann-Zofie Duvander (Stockholm University, Sweden) and Nicklas Korsell (Swedish Inspectorate of the Social Insurance, Sweden). Based on Swedish register data, the authors examine the question of whether separating can lead couples to share their parental leave more equally. Sweden has adopted a very flexible parental leave system that allows parents to take leave from work to care for their children until the children reach age eight. As some couples split up before their children have reached that age, it is possible to analyse how separation affects the use of leave by parents. The authors assume that separation could lead to a more gender-equal sharing of parental leave. The results of the investigation do not, however, support this hypothesis. The most important finding is that separation causes both fathers and mothers to take less leave. This is probably because economic constraints and career considerations make it less likely that separated parents will claim all of their leave benefits. The authors therefore conclude that the children of separated parents are at a disadvantage, as they are less likely than other children to enjoy spending time with both of their parents.

Elena Moore (University of Cape Town, South Africa) contributes a qualitative case study on Ireland, one of the last countries in Europe to legalise divorce. She notes that although divorce is now legal in Ireland, couples still face onerous legal restrictions, such as a required separation period of 4 years preceding the divorce. Moore draws on qualitative longitudinal interview data from separated and divorced parents and examines how the emotional experience of divorce is shaped by the particular social context. Her study reveals how feelings of fear can arise in response to structural inequalities that are rooted in a legal system that creates uncertainties for both parents. While fathers fear a loss of access to their children during the prolonged separation period, mothers fear a loss of power in making parenting decisions. Moore shows how parents "manage" their fears by working with their ex-spouse to develop new ways of parenting.

The chapter by Tina Haux (University of Kent, UK) and Lucinda Platt (London School of Economics and Political Science, UK) addresses the particular role of mothers after union dissolution by investigating whether they report feeling less confident in their parenting efficacy, and, if so, how long this perception lasts. Haux and Platt analyse prospectively collected data on more than 10,000 mothers from the Millennium Cohort Study, a large representative study of children born in the UK in 2000-2001. Each of these mothers was living with the child's father when the 
child was around 9 months old, and was followed until the child was around 7 years old. While the authors observe no initial difference in levels of parenting competence, they find that among the $17 \%$ of mothers who ever separated, their confidence in their parenting declines more than that of non-separated mothers. Even though parenting confidence increases in both groups as the children grow older, separated mothers' perceived parenting competence remains lower than that of coupled mothers. The greater involvement of non-resident fathers does not seem to change this pattern. These findings suggest that the impact of separation on mothers' parenting confidence is long-lasting, given that at least in the current societal context of the UK, a mother who separates has to re-conceive her role as that of a sole parent, and has to deal with widespread negative social perceptions of single mothers.

The last chapter in the section on parent-child relations focuses on the coparenting of ex-partners and its influence on non-resident fathers' contact with their children. Sabine Walper (German Youth Institute and Ludwig-MaximiliansUniversity of Munich, Germany), Stefanie Amberg, Carolin Thönnissen (both Ludwig-Maximilians-University of Munich, Germany), and Sharol L. Christ (German Youth Institute, Germany and Purdue University, USA) investigate different features of maternal gatekeeping after union dissolution, addressing its predictors as well as its effects on father-child contact in Germany. The authors assume that co-parenting problems are an important mediator in the reduction in fatherchild contact that is often observed after a separation. They test their analytic model based on two different datasets: an intervention study that targets a broad range of separated parents (KiB), and the German Family Panel (pairfam). Overall, their findings paint a more nuanced picture of maternal gatekeeping than the image that is often found in the literature. They show that for mothers in particular, having a negative view of the other parent is linked to higher levels of co-parenting conflict, more child-related worries, and the father having less frequent contact with their children. The authors thus conclude that when the mother has an unfavourable view of the father, she is often less willing to facilitate father-child contact. For other features of maternal gatekeeping, such as protective gatekeeping, the analysis finds only limited support. Noting that only a small amount of the variance in father-child contact can be explained by the indicators measuring the quality of co-parenting, the authors suggest that other factors might be more powerful in shaping the frequency of father-child contact.

The book's next section is devoted to the well-being of parents and children after union dissolution. It starts with a chapter by Inge Pasteels and Kim Bastaits (both PXL University of Applied Sciences and Arts, Belgium) that takes the children's perspective into account. Based on data of the multi-actor study Divorce in Flanders (conducted in 2009-2010), the authors investigate feelings of loneliness in relation to different residential arrangements among children between the ages of 10 and 17 . Given that in Belgium joint physical custody after a divorce has been the rule rather than the exception since 2006, the authors are able to compare the emotional wellbeing of children in joint physical custody and in other living arrangements. Their empirical evidence suggests that children's feelings of loneliness are not strongly associated with their living arrangements, but also that children report greater 
feelings of loneliness if their father has multiple post-divorce relationships or if their mother has a new co-residing partner. Overall, the results underline the importance of distinguishing conceptually between different indicators of emotional wellbeing, such as feelings of loneliness, self-esteem, life satisfaction, and depression.

Aušra Maslauskaitè (Vytautas Magnus University, Lithuania) and Anja Steinbach (University of Duisburg-Essen, Germany) focus in their chapter on fathers' wellbeing after union dissolution. Using data from the cross-sectional survey Fathering after Union Dissolution, which was conducted in Lithuania in 2016, they study the extent to which fathers' involvement with their non-resident minor children and the quality of the co-parenting relationship are associated with fathers' psychological well-being. They find that the self-assessed quality of the father's relationship with his child is the most important factor contributing to paternal well-being: i.e., the better the perceived quality of the father-child relationship is, the lower the level of depressive feelings and the higher the level of general life satisfaction the father reports. In addition, they show that while re-partnering has a strong positive impact on fathers' emotional well-being, the frequency of father-child contact and the quality of the co-parenting relationship does not. The authors conclude by observing that the relationship between paternal involvement and well-being is complex.

Katja Köppen (University of Rostock, Germany), Michaela Kreyenfeld (Hertie School, Germany), and Heike Trappe (University of Rostock, Germany) scrutinise the "gendered realities" argument, which asserts that after separation, the wellbeing of mothers and fathers is shaped in different ways. While mothers tend to suffer from a loss of income, fathers often face reduced contact with their children. Using 10 years of panel data from the German Family Panel (pairfam), the authors confirm previous findings indicating that following a separation, satisfaction with family life declines more among fathers than among mothers, and that mothers tend to report a greater reduction in their satisfaction with their household's financial situation than fathers. They also show that, contrary to expectations, physical custody arrangements are only weakly associated with parental well-being. Whether parents practise shared parenting is not shown to positively or negatively influence their well-being. Instead, being employed is found to be the decisive factor in parents' satisfaction with their household's financial situation. Again, it emerges that re-partnering has a large positive impact not only on the father's but also on the mother's well-being. The authors discuss the lack of a clear concept of shared parenting in the social sciences and its consequences for operational definitions, which might, in turn, influence the empirical results.

The concluding section of the book deals with the health-related implications of divorce and separation. Katya Ivanova (Tilburg University, the Netherlands) and Matthijs Kalmijn (University of Amsterdam, the Netherlands) turn their attention to young Dutch adults between 25 and 35 years of age. Based on data from the OKiN survey (Parents and Children in the Netherlands), they focus on self-reported depressive feelings by young adults, and examine whether these feelings are associated with family instability experienced during childhood. In particular, the authors investigate whether having experienced a parental separation or having lived with a stepparent in childhood are related to mental health later on. In addition, they look 
at whether parental union dissolution and living in a stepfamily are only detrimental in cases of conflict, either between the respondent's separated parents or between the respondent and the stepparent. In line with previous research, they find that parental union dissolution has long-term effects on the children involved, as it increases their level of depressive symptoms. Furthermore, their findings clearly underline the role conflict plays in the association between family turmoil during childhood and maladjustment in adulthood, providing support for the "good divorce" and the "good stepparent" hypotheses. The authors conclude that having experienced parental separation is associated with an increase in depressive symptoms only for those young women and men who were exposed to heightened postseparation conflict between their parents, and that having lived with a stepparent is only detrimental in cases of high levels of stepparent-child conflict.

Daniel Brüggmann (Hertie School, Germany) uses rich linked administrative data from the statutory German pension system to study the relationship between divorce and work disability in West Germany, and thus also focuses on long-term health issues. He compares women and men over a period of 7 years before and 4 years after a divorce. To isolate the impact of divorce on the uptake of work disability, the divorcees are matched with a comparable control group of individuals who did not undergo divorce. In Germany, work disability is defined as sick leave that is taken after 6 weeks of illness. Thus, individuals on work disability leave are unable to fully participate in the labour market and often lack access to secure income. The empirical evidence shows that the health of divorcees declines considerably around the time of separation, and that their risk of claiming work disability is strongly elevated even 4 years after a divorce. On average, women's post-divorce health status is found to recover more quickly than that of men. The chapter also points to the importance of selection and reversed causality. The health status of the divorcees had been lower than that of the control group in the period preceding the divorce. Thus, poor health may be not just a consequence, but a cause of increased divorce risk.

\section{Conclusions and Possible Avenues for Future Research}

This volume focused on the effects of union dissolution on parents. Union dissolution is a major "life course risk" (Vandecasteele 2011: 249) that affects parents' economic and social well-being, employment and earnings, health, and parenting behaviour. However, context matters. Social policies can buffer families against some of the adverse consequences of union dissolution (Diewald 2016; DiPrete 2002). Prior work has emphasised the role of work-family policies in the economic well-being of separated parents. More recently, scholars have stressed that the legal frameworks and the corresponding policies that regulate physical custody arrangements for children are increasingly affecting parents' economic and social wellbeing. Despite some modest efforts by the European Union to provide guidelines for harmonised regulations, post-separation policies still vary widely across European countries. On the one hand, Europe seems to be an ideal laboratory for researchers 
who are interested in investigating the effects of post-separation policies. On the other hand, we still lack a comparable and comprehensive European database that maps post-separation policies. Indeed, there is not even a common definition of shared physical custody across countries. Thus, it would be beyond the scope of such a volume to claim that the European experience can be used to distinguish clear-cut policy effects. The contribution of this volume is more modest. It brings together novel research on how separation and divorce influence different life course domains of parents in selected European countries, allowing us to contextualise the findings. There is ample evidence that within societies, the life course implications of a union dissolution depend strongly on an individual's social position with respect to, for instance, gender, education, and social class; and can therefore lead to cumulative disadvantages for particularly vulnerable groups (Leopold 2018; Popova and Navicke 2019; Vandecasteele 2011). This volume also sheds light on how social, cultural, and legal conditions within societies shape parental life courses after family dissolution, and highlights the potential ramifications of these patterns for social stratification.

We have included only a few countries in this study: namely, Belgium, Germany, Ireland, Lithuania, the Netherlands, Sweden, and the UK. Yet the contributions on even this small number of countries demonstrate the variety of policy regulations, parenting practices, and living arrangements that exist among divorced and separated parents across Europe. The studies also illustrate that divorce and separation "operate" in context-specific ways. For example, divorce seems to push women in Germany into the labour market, facilitating their economic independence and longterm labour market integration (see the chapter by Radenacker in this volume). In Sweden, by contrast, female employment rates are generally high. Thus, divorce and separation do not affect women's employment decisions to the same extent in Sweden as they do in Germany. Nylin (in this volume) even finds that the earnings trajectories of separated mothers in Sweden are not as steep as those of partnered mothers. Although the earnings of separated mothers are, overall, more favourable in Sweden than in Germany, there are particular groups of mothers in Sweden who have a low earnings potential, and for whom a separation represents a severe life course risk.

Shared parenting is another area that seems highly context-specific. This arrangement is now widespread in several European countries, including Sweden and Belgium. But in other countries where shared parenting is not yet common, such as Germany and Ireland, co-parenting after divorce and separation can place significant pressure on parents (see the chapters by Köppen et al.; Moore; Walper et al. in this volume). Cherlin (1978) once characterised the stepfamily as an "incomplete institution" due to the lack of normative prescriptions about how such families should act. The same can be said of co-parenting today. Several countries lack a legal framework that regulates co-parenting, and, above all, these countries lack a culture that fosters positive communication between ex-partners. The role of fathers has been changing in recent years, and fathers increasingly want to stay involved in their children's lives beyond separation. However, negotiating parental and care responsibilities after separation and divorce can be burdensome and challenging for 
ex-partners, especially in countries where shared parenting is still uncommon (see also Steinbach 2019).

Almost all of the contributions in this volume emphasise that in order to understand post-separation behaviour, it is important to consider the life course, and, thus, the role of path dependency. While we have some insight into how early life conditions affect health and well-being after divorce and separation (e.g., chapters by Brüggmann; Ivanova and Kalmijn in this volume), some related questions have yet to be examined. For example, does a father's level of involvement in childcare prior to separation correspond to his level of engagement in his children's lives after the break-up? Is a father who had previously taken parental leave more likely than other fathers to ask for joint physical custody? Or is the likelihood of seeking joint physical custody unrelated to a father's level of involvement before the break-up? While it is important for family counsellors, family law professionals, and policy-makers to be able to provide reliable information about these issues and to answer questions of this kind, the comprehensive life course data that would be needed to do so are rarely available (for an exception, see, e.g., Poortman 2018).

The contributions that are assembled in this volume use high-quality data drawn from small and large surveys, administrative data, and in-depth interviews to depict how parents and children fare after divorce and separation in a broad range of European countries. Unfortunately, a direct comparison across countries was often not possible because the population included in the different types of datasets differed. A particular problem was that some datasets cover only divorcees, while others also cover ex-partners who had not been married. Landmark studies like "Divorce in Flanders" include only divorcees (e.g., Pasteels and Bastaits in this volume). Nordic register data enable researchers to identify the dissolution of a nonmarital union (e.g., Nylin in this volume), but register data for Germany and Belgium cover only divorcees (e.g., Mortelmans et al.; Radenacker in this volume). As marriage rates decline and ratios of non-marital childbearing rise, investigations that focus on divorcees only are becoming increasingly selected. Thus, there appears to be a consensus that future research should focus on union instability instead of divorce. This premise is reflected in recent family surveys that are designed to collect complete union histories (e.g., Ivanova and Kalmijn in this volume). However, the terminology surrounding union dissolution seems to be more "sticky". The main network of European research in this area is the "Divorce Network", which hosts an annual "Divorce Conference". Most of the studies conducted under the heading of "divorce research" are on the causes and consequences of union (in)stability. Thus, it seems high time to reflect that reality through a change in terminology.

Acknowledgments We thank the German Science Foundation under the Grant Agreement (under Grant Number 266395921) for supporting our research. 


\section{References}

Albertini, M., \& Garriga, A. (2011). The effect of divorce on parent-child contacts: Evidence on two declining effect hypotheses. European Societies, 13(2), 257-278. https://doi.org/10.108 $0 / 14616696.2010 .483002$.

Andersson, G., Thomson, E., \& Duntava, A. (2017). Life-table representations of family dynamics in the 21st century. Demographic Research, 37(35), 1081-1230. https://doi.org/10.4054/ DemRes.2017.37.35.

Andreß, H.-J., Borgloh, B., Brockel, M., Giesselmann, M., \& Hummelsheim, D. (2006). The economic consequences of partnership dissolution: A comparative analysis of panel studies from Belgium, Germany, Great Britain, Italy, and Sweden. European Sociological Review, 22(5), 533-560. https://doi.org/10.1093/esr/jc1012.

Bennett, N. G. (2017). A reflection on the changing dynamics of union formation and dissolution. Demographic Research, 36(12), 371-390. https://doi.org/10.4054/DemRes.2017.36.12.

Cancian, M., Meyer, D. R., Brown, P. R., \& Cook, S. T. (2014). Who gets custody now? Dramatic changes in children's living arrangements after divorce. Demography, 51(4), 1381-1396. https://doi.org/10.1007/s13524-014-0307-8.

Cherlin, A. J. (1978). Remarriage as an incomplete institution. American Journal of Sociology, 84(3), 634-650. https://doi.org/10.1086/226830.

Claessens, E., \& Mortelmans, D. (2018). Challenges for child support schemes: Accounting for shared care and complex families. Journal of European Social Policy, 28(3), 211-223. https:// doi.org/10.1177/0958928717753592.

Cohen, P. N. (2019). The coming divorce decline. Socius: Sociological Research for a Dynamic World, 5. https://doi.org/10.1177/2378023119873497.

Diewald, M. (2016). Life course risks and welfare states' risk management. In M. J. Shanahan, J. T. Mortimer, \& M. Kirkpatrick Johnson (Eds.), Handbook of the life course (pp. 677-687). Cham: Springer.

DiPrete, T. A. (2002). Life course risks, mobility regimes, and mobility consequences: A comparison of Sweden, Germany, and the United States. American Journal of Sociology, 108(2), 267-309. https://www.jstor.org/stable/10.1086/344811.

Eurostat. (2019). Divorce indicators [demo_ndivind]. https://ec.europa.eu/eurostat/data/database.

Gałęzewska, P., Perelli-Harris, B., \& Berrington, A. (2017). Cross-national differences in women's repartnering behaviour in Europe: The role of individual demographic characteristics. Demographic Research, 37(8), 189-228. https://doi.org/10.4054/DemRes.2017.37.8.

Halman, L., \& van Ingen, E. (2015). Secularization and changing moral views: European trends in church attendance and views on homosexuality, divorce, abortion, and euthanasia. European Sociological Review, 31(5), 616-627. https://doi.org/10.1093/esr/jcv064.

Härkönen, J. (2014). Solomonic choices: Parental separation, child well-being and family policies in Europe. European Policy Brief 1. http://www.familiesandsocieties.eu/wp-content/ uploads/2014/12/EuropeanPolicyBrief1_FamiliesAndSocieties.pdf

ISSP Research Group. (1997). International social survey programme: Family and changing gender roles II - ISSP 1994. GESIS Data Archive, Cologne. ZA2620 Data file Version 1.0.0. https:// doi.org/10.4232/1.2620.

ISSP Research Group. (2013). International social survey programme: Family and changing gender roles III - ISSP 2002. GESIS Data Archive, Cologne. ZA3880 Data file Version 1.1.0. https://doi.org/10.4232/1.11564.

ISSP Research Group. (2016). International social survey programme: Family and changing gender roles IV. ISSP 2012. GESIS Data Archive, Cologne. ZA5900 Data file Version 4.0.0. doi:https://doi.org/10.4232/1.12661.

Ivanova, K., Kalmijn, M., \& Uunk, W. (2013). The effect of children on men's and women's chances of re-partnering in a European context. European Journal of Population, 49(4), 417-444. https://doi.org/10.1007/s10680-013-9294-5. 
Jansen, M., Mortelmans, D., \& Snoeckx, L. (2009). Repartnering and (re)employment: Strategies to cope with the economic consequences of partnership dissolution. Journal of Marriage and Family, 71(5), 1271-1293. https://doi.org/10.1111/j.1741-3737.2009.00668.x.

Kalmijn, M. (2015). Father-child relations after divorce in four European countries: Patterns and determinants. Comparative Population Studies - Zeitschrift für Bevölkerungsforschung, 40(3), 251-276. https://doi.org/10.12765/CPoS-2015-10en.

Leopold, T. (2018). Gender differences in the consequences of divorce: A study of multiple outcomes. Demography, 55(3), 769-797. https://doi.org/10.1007/s13524-018-0667-6.

Lesthaeghe, R. (1983). A century of demographic and cultural change in Western Europe: An exploration of underlying dimensions. Population and Development Review, 9(3), 411-435.

Lesthaeghe, R. (2010). The unfolding story of the second demographic transition. Population and Development Review, 36(2), 211-251. https://doi.org/10.1111/j.1728-4457.2010.00328.x.

Matysiak, A., Styrc, M., \& Vignoli, D. (2014). The educational gradient in marital disruption: A meta-analysis of European research findings. Population Studies, 68(2), 197-215. https://doi. org/10.1080/00324728.2013.856459.

McLanahan, S. (2004). Diverging destinies: How children are faring under the second demographic transition. Demography, 41(4), 607-627. https://doi.org/10.1353/dem.2004.0033.

Meyer, D. R., \& Carlson, M. J. (2014). Family complexity: Implications for policy and research. The Annals of the American Academy of Political and Social Science, 654(1), 259-276. https:// doi.org/10.1177/0002716214531385.

Musick, K., \& Michelmore, K. (2018). Cross-national comparisons of union stability in cohabiting and married families with children. Demography, 55(4), 1389-1421. https://doi.org/10.1007/ s13524-018-0683-6.

Perelli-Harris, B., \& Lyons-Amos, M. (2016). Partnership patterns in the United States and across Europe: The role of education and country context. Social Forces, 95(1), 251-282. https://doi. org/10.1093/sf/sow054.

Poortman, A.-R. (2018). Postdivorce parent-child contact and child well-being: The importance of predivorce parental involvement. Journal of Marriage and Family, 80(3), 671-683. https://doi. org/10.1111/jomf.12474.

Popova, D., \& Navicke, J. (2019). The probability of poverty for mothers after childbirth and divorce in Europe: The role of social stratification and tax-benefit policies. Social Science Research, 78(1), 57-70. https://doi.org/10.1016/j.ssresearch.2018.10.007.

Raeymaeckers, P., Dewilde, C., Snoeckx, L., \& Mortelmans, D. (2008). Childcare strategies of divorced mothers in Europe: A comparative analysis. European Sociological Review, 24(1), 115-131. https://doi.org/10.1093/esr/jcm040.

Rijken, A., \& Liefbroer, A. (2012). European views of divorce among parents of young children: Understanding cross-national variation. Demographic Research, 27(2), 25-52. https://doi. org/10.4054/DemRes.2012.27.2.

Schnor, C. (2014). The contexts of partnership and childbearing as determinants of union stability: A quantitative analysis on western and eastern German partnerships with data from the German Family Panel. Rostock: Max Planck Institute for Demographic Research: https:// www.demogr.mpg.de/en/projects_publications/publications_1904/dissertations/the_contexts_ of_partnership_and_childbearing_as_determinants_of_union_stability_a_quantitative_5344. htm. Accessed 19 Aug 2019.

Spijker, J., \& Solsona, M. (2012). Atlas of divorce and post-divorce indicators in Europe (Papers de Demografia 412). Universitat Autònoma de Barcelona (Spain): https://docs.google.com/ file/d/0B5AdSqP9auWvTmg4RnJTMGRtMUE/edit. Accessed 20 July 2019.

Steinbach, A. (2019). Children's and parents' well-being in joint physical custody: A literature review. Family Process, 58(2), 353-369. https://doi.org/10.1111/famp.12372.

Van Bavel, J., Schwartz, C. R., \& Esteve, A. (2018). The reversal of the gender gap in education and its consequences for family life. Annual Review of Sociology, 44, 341-360. https://doi. org/10.1146/annurev-soc-073117-041215. 
Vandecasteele, L. (2011). Life course risks or cumulative disadvantage? The structuring effect of social stratification determinants and life course events on poverty transitions in Europe. European Sociological Review, 27(2), 246-263. https://doi.org/10.1093/esr/jcq005.

Weziak-Bialowolska, D. (2015). Differences in gender norms between countries: Are they valid? The issue of measurement invariance. European Journal of Population, 31(1), 51-76. https:// doi.org/10.1007/s10680-014-9329-6.

Open Access This chapter is licensed under the terms of the Creative Commons Attribution 4.0 International License (http://creativecommons.org/licenses/by/4.0/), which permits use, sharing, adaptation, distribution and reproduction in any medium or format, as long as you give appropriate credit to the original author(s) and the source, provide a link to the Creative Commons license and indicate if changes were made.

The images or other third party material in this chapter are included in the chapter's Creative Commons license, unless indicated otherwise in a credit line to the material. If material is not included in the chapter's Creative Commons license and your intended use is not permitted by statutory regulation or exceeds the permitted use, you will need to obtain permission directly from the copyright holder.

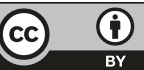

